\title{
European English in the EFL classroom?
}

\author{
SUSANNE MOHR, SANDRA JANSEN AND JULIA \\ FORSBERG
}

Teacher attitudes towards target varieties of English in Sweden and Germany

\section{Introduction}

The UK is facing important changes in the near future, with Brexit, i.e. the UK leaving the European Union (EU), looming ever more closely on the horizon. These important political and economic changes will certainly have an influence on Europe as a whole, and have had linguistic consequences for the English language, such as Brexit-related neologisms (Lalić-Krstin \& Silaški, 2018). As Modiano (2017a) suggests, Brexit might also have an influence on the status of the English language in the EU, in particular with regard to the dominance of native speaker varieties. In this article, we discuss the possibility of the use of a neutral European English variety in the EFL classrooms of two EU member states, i.e. Sweden and Germany. Based on a survey among 80 practitioners in secondary schools (first results were presented in Forsberg, Mohr \& Jansen, 2019), the study investigates attitudes towards target varieties of English in general, and European English or 'Euro-English' (cf. Jenkins, Modiano \& Seidlhofer, 2001; Modiano 2003) in particular, after the referendum in June 2016.

\section{Teaching English in Europe: between communicative competence and target accents}

English is widely used across Europe, not only in those countries where it is the official and/or first language (e.g. Malta and most parts of Ireland), but also in other countries, where it is usually used for international communication purposes. In the countries where it is used for international communication, it is usually taught and acquired as a foreign language (EFL). However, its status as an EFL in some European countries has been recently questioned (Modiano, 2017b), as an unequivocal distinction between foreign and second language (ESL) no longer seems sustainable in the era of globalisation (Bruthiaux, 2003). For example, in Scandinavian countries and in the Netherlands, the increased societal use of English makes a clear distinction between second and foreign language difficult (cf. Sundqvist \& Sylvén, 2014; Edwards, 2016), if at all desirable.

Educational language policies and curricula concerning English in countries that do not use it as either official or first language are, however, similar in terms of a recent move towards an emphasis on communicative competence as teaching goal. Thus, the Sekretariat der Ständigen Konferenz der Kultusminister der Länder in der Bundesrepublik Deutschland (2014: 14, 19) in Germany included 'functional communicative competence' and 'intercultural communicative competence' in their educational standards for English as a foreign language. Both contribute to 'discursive competence', including the abilities in the areas of listening comprehension, reading comprehension, writing, speaking and linguistic mediation (Sekretariat der Ständigen Konferenz der Kultusminister der Länder in der Bundesrepublik Deutschland, 2014: 12). Similarly, the decree for education states Swedish schools is to ensure that, after completing compulsory school, every pupil can communicate in English, verbally and in writing (Swedish Government, 2018: 11). The decree further outlines the purpose and aims of learning English in the Swedish school system, and concludes that 


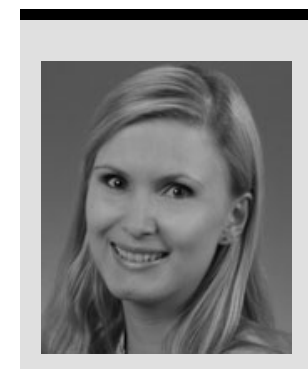

SUSANNE MOHR is a senior lecturer in Applied English Linguistics at the University of Bonn, Germany. Her research interests include varieties of English, especially in Africa, sign languages, and sociolinguistics, specifically multilingualism, language

contact, language in education, and language and tourism. She wrote her postdoctoral dissertation (2018) on pluralisation strategies and countability in African varieties of English. She is a member of several scientific networks, such as the Irish Deaf Research Network, the Humboldt Alumni Network and the North Rhine-Westphalian Academy of Sciences, Humanities and the Arts. Email: susanne. mohr@uni-bonn.de

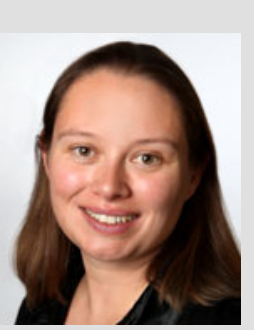

SANDRA JANSEN is a senior lecturer in English linguistics at the University of Paderborn, Germany. Her research focuses on language variation and change, Cumbrian English, sociophonetics and variation in production and perception of L2 varieties of English.

Recently, she edited a volume on Sociolinguistics in England (Palgrave; with Natalie Braber) and a volume on Processes of Change. Studies in Late Modern and Present-Day English (John Benjamins; with Lucia Siebers).Email: sandra.jansen@unipaderborn.de

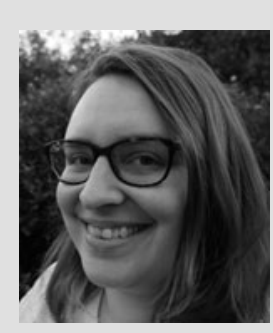

JULIA FORSBERG is a senior lecturer in Swedish as a second language at Stockholm University, as well as a lecturer in English at Jönköping University. In her PhD thesis she studied different aspects of English in Sweden, including experiences and views of

English teachers. She is currently a part of IntensiveSwedish, a development project working with the language introductory programme for newly arrived adolescents in Sweden. Her research interests include phonology and language learning, multilingualism in school contexts and beyond. Email: Julia.backelin-forsberg@su.se

the 'Communication skills also cover confidence in using the language and the ability to use different strategies to support communication and solve problems when language skills by themselves are not sufficient' (Swedish Government, 2018: 34). Aside from references to cultural exchanges and using English as a tool to communicate with others, the only reference to different varieties of English is in the outline of course contents, where it is stated that pupils will listen to 'Spoken English with slight regional and social accents' (Swedish Government, 2018: 37).

However, driven by long-lasting ideologies of teaching (in) native varieties of English, i.e. British English (BrE) and American English (AmE), this focus on communicative competence is not always fully implemented in the classroom, as recent studies have shown: an orientation towards these two native English target accents is still present in many EFL classrooms, with different preferences for either BrE or AmE in different countries (Forsberg et al., 2019). This theorypractice divide between learned speaking ideals and didactic goals (Galloway, 2017) might be resolved by (a) increased provision of better suited teaching materials utilising a more varied basis of targets (Matsuda, 2012) and (b) by an emphasis on didactic ideals in relation to target varieties in theoretical and practical teacher training (Mora \& Golovátina-Mora, 2017; Forsberg et al., 2019). These solutions would, inevitably, involve the consideration of such concepts as English as a Lingua Franca (ELF) or a European variety of English (Modiano, 2017b), and ultimately question the ideologies behind the stance of 'sounding native'.

\section{The concept of European English}

The use of a variety of English which is detached from ideologically loaded native varieties such as $\mathrm{BrE}$ and AmE for communication in Europe and in the EFL classroom in particular has been discussed previously in the literature. It allows for an increased orientation towards communicative competence as a teaching goal, which is emphasised by such concepts as ELF (e.g. Seidlhofer, Breiteneder \& Pitzl, 2006). Concrete examples of accommodation concerning pronunciation in interactions between non-native speakers, have also been put forth (Jenkins, 2000). Thus, a core of lingua franca features supposedly contribute to intelligibility in lingua franca situations, specifically features such as vowel length distinctions or the realization of consonant phonemes apart from the dental fricatives.

When asked, however, practitioners do not react very positively to these suggestions. For instance, in their focus group study with teachers from around the world, Johnstone Young and Walsh 
(2010) showed that a majority did not want to use an ELF model for teaching, as it was perceived to be 'not standard', 'broken' or 'simplified'. Similarly, the German university students in Gnutzmann, Jakis and Rabe's (2015) study felt that 'Euro-English' would be a bad imitation of 'real' English and maintained that English belongs to its native speakers. On the other hand, quantitative studies of EFL learners found that the participants' actual language use did not correspond to $\mathrm{BrE}$ or AmE as target model but that they used features from a feature pool (cf. Mufwene, 2001) to distance themselves from native speaker varieties (Rindal \& Piercy, 2013, for Norwegian learners; Jansen \& Langstrof, forthcoming, for German learners). Hence, a mismatch between the teachers' ideological values and the students' production seems to exist. 'ELF is already a complex phenomenon and any attempt to integrate it in ELT is bound to be impacted by stakeholders' attitudes and established ELT practices fuelled by the predominance of native-speakerist perspectives' (Sifakis, 2019: 289).

Modiano (2017a: 12) suggests that the introduction of a neutral European variety of English would have important identity-providing function, 'liberat [ing] continental European L2 users of English from the tyranny of standard language ideology', especially with important political changes like Brexit looming on the horizon. These impending changes and suggestions could be a chance to revisit the prevailing $\mathrm{BrE}$ and $\mathrm{AmE}$ ideologies in classrooms throughout Europe. Here, we investigate the acceptability of a neutral European variety of English by EFL teachers in two countries, Sweden and Germany. Both countries emphasise the role of communicative competence in recent curricula as mentioned above, but show differing uses of English in society, with Swedes being exposed to it much more than Germans (Forsberg et al., 2019).

\section{Teachers' attitudes towards European English}

In the 2016 Brexit referendum aftermath we were wondering what status BrE has among EFL teachers in Sweden and Germany and how the status of target varieties relates to the communicative approach to EFL teaching which is now promoted in both countries (Forsberg et al., 2019). This was investigated in the form of an online questionnaire, administered to 80 teachers (46 in Sweden and 34 in Germany) with an average age of $39.6(\mathrm{SD}=8.5)$ and an average of 11.4 years of teaching experience $(\mathrm{SD}=7.6)$, at the beginning of 2017. It was piloted in a pre-test with eight Swedish and eight German participants. The final questionnaire contained 35 questions concerning the teacher's personal language learning history and official teacher training, but the majority of the questions $(\mathrm{N}=23)$ concerned their teaching practices, i.e. official instructions concerning their teaching, methods used to teach different aspects of the English language such as pronunciation or grammar or the nature of materials used for teaching these aspects.

Answers concerning the inclusion of a European variety of English in the classroom, together with the general results on the use of varieties in the classroom, proved intriguing. One particular question targeting European English in the questionnaire was formulated in the following way:

Several researchers have proposed the introduction of Euro-English, a distinct European variety consisting of the most frequent English language features throughout Europe, to English language teaching. Could you imagine using a variety like this for your own teaching?

Why/why not?

Not all teachers gave reasons for their answers to this question. Here, only those participants are considered that justified their answers $(\mathrm{N}=16)$. A small majority of these participants $(\mathrm{N}=9$, six of them German, three of them Swedish) said they would not use European English in their teaching. Their reasons are different, although many refer to the non-nativeness or supposedly unnatural character of this variety, as shown in (1), (2) and (3).

(1) Pre-Ger1f': 'No because I believe that British English is easy to understand and repeat by learners and I think that learning a language based on a "native/natural" example is better than learning it based on some made-up variation.'

(2) Pre-Ger8f: 'No, I still see native-like speaking as the goal of teaching.'

(3) Pre-Swe2m: 'I wouldn't, when we teach a language ti $[s i c]$ out $[s i c]$ students we also teach them about the culture and history of that language.'

(3) is especially interesting, as the teacher does not mention nativeness or naturalness directly, but rather refers to the lack of cultural background of this kind of variety. Thus, right now European English does not seem to have an identityproviding function for our participants, as was 
suggested by Modiano (2017a). This is emphasised by another participant, who feels that there are already several European Englishes, which should not be artificially subsumed under one label and standardised.

(4) Pre-Swe8m: 'These varieties already exist, although not officially, as local varieties of the English taught in every European country. I'm not sure that trying to standardize it and adding more variety to the already quite diverse English language would simplify things that much for students. In short, I do not believe that we would benefit from this, so no.'

Other participants might be open to the use of this kind of variety, but cannot imagine it at the moment, as they do not know enough about it. Among the participants who could imagine using European English $(\mathrm{N}=7)$, the argument of knowledge about the concept is also brought forth:

(5) Pre-Ger5m: 'I would have to do more research into this first but I could imagine doing it if the curriculum allowed it. I doubt this will be a consequence of Brexit though. I don't believe Brexit will have a huge impact on German-British relations.'

The lingua franca aspect, as well as use in real life situations, motivates several other teachers to consider the idea, as shown in (6) and (7).

(6) Pre-Ger7f: 'Yes because German learners of English get increasingly in contact with English speaking people in Europe (more than American people e.g.)'

(7) Pre-Swe6f: 'Yes, since English has emerged as a Lingua Franca, I do believe there should be more "international" varieties taught.'

However, here, too native varieties of English and their influences are mentioned.

(8) Pre-Swe1f: 'Sure, but I think American and British will always be dominating.'

Interestingly, the ownership of English is also mentioned in this group but rather in relation to appropriating the language.

(9) Pre-Swe5m: 'Yes, I certainly would. Right now, speaking RP or GA seems more like one is imitating another native rather than speaking "their own English dialect".'

This turns the argument of naturalness around, maintaining that imitating somebody else's way of speaking is anything but natural and using another (even artificial) dialect would be preferable to this. Importantly, it illustrates that some teachers are very critical of the ideological load of native varieties as ultimate teaching goals and certainly want to implement the turn towards communicative competence established in recent curricula.

\section{Teachers' reported use of other varieties of English}

In contrast to the critical attitudes expressed towards native varieties outlined previously, in their responses to questions on language use, the majority of our teacher participants reported they use either BrE or AmE in private and in the classroom (Forsberg et al., 2019: 43, 45). They also feel they are able to switch between these (and other varieties) freely in different situations (Forsberg et al., 2019: 51). The discrepancy between the use of standard varieties in the classroom and the critical attitudes expressed in response to the question on European English, as well as general comments on the questionnaire (cf. example (10) and Forsberg et al., 2019: 50), possibly relate to the oftcited theory-practice divide (e.g. Galloway, 2017) in EFL teaching. While teachers might be aware of the (ideological) load of native varieties, it is difficult for them to practically implement more communicatively oriented approaches in class, e.g. due to a lack of appropriate materials (Matsuda, 2012).

(10) Ger26m: 'This questionnaire seems to center on varieties of English which seems odd to me. This is (by far) the least important aspect of teaching English. The goal is to enable students to communicate. Even a total confusion of all varieties of English would be acceptable as long as it gets the job (successful communication) done. I am aware that this has not always been the case in German educational doctrine but there has been a push in that direction in recent years and for once, that's a change that I agree with.'

Comparing the data from the Swedish and German participants, an interesting difference concerning reported language use emerges though. There are nine Swedish participants out of 46 who report using no specific variety in private, and 11 who report not using a specific variety when teaching speaking skills, as well as 14 who reportedly do not use any specific variety when they teach writing skills. This is notably different to the German participants, of whom onle one out of 34 reported not using a specific variety of English privately (Forsberg et al., 2019: 43, 45). This demonstrates 
the Swedish participants' greater openness towards, or possibly detachment from, native speaker ideologies. It is emphasised by one Swedish participant reporting the use of 'Mid-Atlantic English' (Modiano, 2002), a mixture of American and British English pronunciation features which is not used by native speakers of English, making it similar to an artificial variety of English like Euro-English. This tendency among the Swedish teachers in this study is in line with Rindal and Piercy's (2013) and Aiello's (2018) reports of European speakers of English aiming for fluent non-nativeness and at the same time distancing themselves from native language ideologies. There are, hence, teachers in our sample who can imagine using (and in fact do use) an artificially created variety of English in teaching, a fact that raises the question as to why they cannot imagine using Euro-English. One possible reason might be the rather abstract nature of the concept: our participants mention explicitly that they do not know enough about this variety (cf. example (5) and (11) below). We do know it is supposedly similar to ELF, but this does not have any 'fixed' features either (Seidlhofer et al., 2006).

(11) Pre-Ger2m: 'at the moment no, because at the moment I do not have any substantial theoretical basis.'

This lack of information on the variety makes the question in our questionnaire difficult to answer and we cannot in fact determine whether all participants had the same concept in mind when answering it. While this is a weakness of our research instrument, it is due to the lack of information on the concept provided in the literature. As such, it remains a theory with little practical application for teachers.

\section{Discussion of teachers' attitudes and reported language use}

Altogether, the response of our participants concerning the introduction and use of a European variety of English in their teaching is rather lukewarm. Apart from the abstract nature of the concept mentioned above, other aspects possibly accounting for their reluctance can be summarised as follows:

1. They learned BrE or AmE and (subconsciously) feel they need to stick to these native norms due to the strong ideological values of these varieties.

2. They're not necessarily bothered by the native/ non-native distinction but they do not think there are any benefits to introducing a new variety in the classroom, which they perceive as 'constructed'.

3. Learning a new variety costs time and energy and with increasing work pressures, e.g. because of more rigorous testing, teachers are probably discouraged by the extra work.

This summary amply illustrates that there is a practical side to the discussion of European English in the classroom, and, perhaps more importantly, an ideological one. As mentioned in the beginning, the tradition of teaching (in) native varieties of English is long-lasting in Europe and seems deeply ingrained in the participants' conceptualisation of the English language and its use. This closely relates to the construction of identity: an 'artificial' European variety of English does not (yet) seem to be identity-providing as suggested by Modiano (2017a), which is in line with Gnutzmann, Jakis and Rabe's (2015) results. On the other hand, our participants seem attached to the ways in which they speak English and do not want to change them, possibly because they are in a way identityproviding for them. This, however, refers to their individual ways of using English and not so much to an overarching European variety that would, if implemented officially, be yet another imposed standard. This individual language use seems very well suited for communication, including private matters (cf. Forsberg et al., 2019), in contrast to Gnutzmann et al.'s (2015) suggestion that a common European variety of English would be particularly well suited for communication within Europe. Individual varieties exist, and they are perceived as useful.

Besides the issue of identity, correctness is a recurring and important theme in our participants' answers. Several teachers mention correctness of language use as particularly important for their teaching, as shown in examples (12) and (13), responses to the question whether the teacher would allow variants from other varieties of English on a test.

(12) Ger11f: 'Yes, if I know that these variants are correct. I indicate that they deviate from British English (AE, IE, ...)'

(13) Ger29f: 'probably not, because I don't know every single variant of English out there and to my mind students should be consistent in the variant they use, which is usually either British or American (it'd be different if I knew the student was part Irish or Nigerian or whatever and I could trust that their English is a native speaker's English).' 
Modiano (2017a: 320) explains that particularly native English speakers 'defend the correct rendition of [English]'. However, correctness, as shown in the responses above, is also very much associated with nativeness and 'authentic' use of English by the German and Swedish participants. The above responses, especially example (13), also foreground the issue of naturalness and authenticity again. A speaker's language use is considered only valid, i. e. correct, if they are a native speaker of a variety. While this attitude illustrates how deeply ingrained the ideal of the native speaker is among the participants, it might at the same time be a practical requirement: teachers need a yardstick for assessment and it is natural and logical that they will choose one they are already familiar with. It is here that new ideas in terms of materials and approaches are needed to successfully implement the curriculum turn towards communicative competence over (native speaker) target varieties.

\section{A conclusion, of sorts}

In light of the views expressed in our study, it does not seem as if German and Swedish teachers would very much welcome the use of a unified European English variety in their teaching at this point in time. This is due to ideological as well as practical reasons which might, however, be influenced by such large-scale political events as Brexit. Some teachers, especially in Sweden, already use more ideologically neutral varieties of English than the traditional native target varieties $\mathrm{BrE}$ and $\mathrm{AmE}$, thus emphasising the idea of communicative competence as teaching goal. Individual European Englishes seem very well suited for (international) communication and time will tell whether they can and will substitute native targets in European EFL classrooms.

\section{Note}

1 The IDs provided reflect the participants' nationality (Ger or Swe), number in our data set and sex (f or m; nobody indicated "diverse"). Further, 'Pre-' indicates that a comment is taken from the pre-test executed for our study.

\section{References}

Aiello, J. 2018. Negotiating Englishes and English-Speaking Identities: A Study of Youth Learning English in Italy. Oxon: Routledge.

Bruthiaux, P. 2003. 'Squaring the circles: Issues in modeling English worldwide.' International Journal of Applied Linguistics, 13(2), 159-178.

Edwards, A. 2016. English in the Netherlands: Functions, Forms and Attitudes. Amsterdam: John Benjamins.

Forsberg, J., Mohr, S. \& Jansen, S. 2019. “"The goal is to enable students to communicate." Communicative competence and target varieties in TEFL practices in Sweden and Germany.' European Journal of Applied Linguistics, 7(1), 31-60.

Galloway, N. 2017. Global Englishes and Change in English Language Teaching: Attitudes and Impact. Abingdon: Routledge.

Gnutzmann, C., Jakis, J. \& Rabe, F. 2015. 'Communicating across Europe. What German students think about multilingualism, language norms and English as a lingua franca.' In A. R. Linn, N. Bermel \& G. Ferguson (eds.), Attitudes towards English in Europe. Berlin et al.: Mouton de Gruyter, pp. 165-191.

Jansen, S. \& Langstrof, C. forthcoming. 'Compiling a speech corpus of German English: A study of variation in the use of rhoticity and the BATH vowel'. In R. Hickey (ed.), English in the German-Speaking World. Cambridge: Cambridge University Press.

Jenkins, J. 2000. The Phonology of English as an International Language: New Models, New Norms, New Goals. Oxford: Oxford University Press.

Jenkins, J., Modiano, M. \& Seidlhofer, B. 2001. 'Euro-English.' English Today, 17(4), 13-19.

Johnstone Young, T. \& Walsh, S. 2010. 'Which English? Whose English? An investigation of 'non-native' teachers' beliefs about target varieties.' Language, Culture and Curriculum, 23(2), 123-137.

Lalić-Krstin, G. \& Silaški, N. 2018. 'From Brexit to Bregret: An account of some Brexit-induced neologisms in English.' English Today, 34(2), 3-8.

Matsuda, A. (ed.) 2012. Principles and Practices of Teaching English as an International Language. Bristol: Multilingual Matters.

Modiano, M. (ed.) 2002. Studies in Mid-Atlantic English. Gävle: HS Institutionens Skriftserie Nr 7.

Modiano, M. 2003. 'Euro-English. A Swedish perspective.' English Today, 19(2), 35-41.

Modiano, M. 2017a. 'English in a post-Brexit European Union.' World Englishes, 36(3), 313-327.

Modiano, M. 2017b. 'Responses to comments.' World Englishes, 36(3), 363-366.

Mora, R. A. \& Golovátina-Mora, P. 2017. 'A new model for reflexivity and advocacy for master's-level EIL in-service programs in Colombia: the notion of 'learning and teaching processes in second languages'.' In A. Matsuda (ed.), Preparing Teachers to Teach English as An International Language. Bristol: Multilingual Matters, pp. 35-50.

Mufwene, S. 2001. The Ecology of Language Evolution. Cambridge: Cambridge University Press.

Rindal, U. \& Piercy, C. 2013. "'Being 'neutral”? English pronunciation among Norwegian learners.' World Englishes, 32(2), 211-229.

Seidlhofer, B., Breiteneder, A. \& Pitzl, M.-L. 2006. 'English as a lingua franca in Europe: challenges for applied linguistics.' Annual Review of Applied Linguistics, 26, 3-34.

Sekretariat der Ständigen Konferenz der Kultusminister der Länder in der Bundesrepublik Deutschland. 2014.

'Bildungsstandards für die fortgeführte Fremdsprache (Englisch/Französisch) für die Allgemeine Hochschulreife.' Köln: Wolters Kluwer. https://www. $\mathrm{kmk}$.org/fileadmin/Dateien/veroeffentlichungen beschluesse/2012/2012_10_18-BildungsstandardsFortgef-FS-Abi.pdf (accessed 18 October 2017). 
Sifakis, N. C. 2019. 'EFL awareness in English language teaching: Principles and processes.' Applied Linguistics, 40(2), 288-306.

Sundqvist, P. \& Sylvén, L. K. 2014. 'Language-related computer use: Focus on young L2 English learners in Sweden.' ReCALL, 26(1), 3-20.
Swedish Government. 2018. 'Curriculum for the compulsory school, preschool class and school age educare.' Revised version. https://www.skolverket.se/publikationsserier/ styrdokument/2018/curriculum-for-the-compulsoryschool-preschool-class-and-school-age-educare-revised2018 id=3984 (accessed 16 September 2019). 